\title{
Antibacterial activity of grepafloxacin
}

\author{
B Wiedemann, P Heisig
}

\begin{abstract}
B Wiedemann, P Heisig. Antibacterial activity of grepafloxacin. Can J Infect Dis 1998;9(Suppl E):4E-9E.
Grepafloxin has an extremely broad spectrum of activity. Its activity against Gram-positive bacteria exceeds that of currently available quinolones. Grepafloxacin-resistant mutants seem to occur less frequently than ciprofloxacin- or ofloxacin-resistant mutants, and the increase in minimum inhibitory concentration (MIC) against the former mutants is less than that of the latter. This applies only to the relative differences (in dilution steps); the absolute values are similar. Grepafloxacin kills Gram-positive bacteria at concentrations little above the MIC. Its pharmacodynamic profile against pneumococci is promising, favouring use of this drug for respiratory tract infections.
\end{abstract}

Key Words: Gram-positive bacteria, Grepafloxacin, Quinolones

\section{L'activité antibactérienne de la grépafloxacine.}

RÉSUMÉ : Le spectre d'activité de la grépafloxacine est très large. Son activité contre les bactéries gram-positives excède celle des quinolones actuellement disponibles. Les mutants résistants à la grépafloxacine semblent moins fréquents que les mutants résistants à la ciprofloxacine ou à l'ofloxacine, et l'augmentation de la concentration minimale inhibitrice (CMI) pour les premiers est plus faible que pour les seconds. Ceci s'applique seulement aux différences relatives (dans les phases de dilution) ; les valeurs absolues sont similaires. La grépafloxacine tue les bactéries gram-positives à des concentrations excédant légèrement la CMI. Son profil pharmacodynamique contre les pneumocoques est prometteur, privilégiant ainsi l'utilisation de ce médicament pour le traitement des infections des voies respiratoires.

4 - Quinolones are potent inhibitors of DNA synthesis (1). Their main targets are two structurally homologous enzymes, DNA gyrase $(2,3)$ and DNA topoisomerase IV $(4,5)$. In Escherichia coli and probably other Gram-negative bacteria, DNA gyrase is the primary target for quinolones (6-8), but in Gram-positive bacteria, such as Staphylococcus aureus and Streptococcus pneumoniae, topoisomerase IV seems to be the primary target $(9,10)$. However, the specificity for a target can vary with the drug (11). Thus, structural alterations in the quinolone molecule can dramatically affect the in vitro and in vivo activity, eg, the antibacterial pharmacodynamics, the pharmacokinetics and the toxicity. Fluorinated quinolones like ciprofloxacin and ofloxacin have gained a wide acceptance for use in the treatment of urinary tract infections, sexually transmitted diseases, skin and soft tissue infections, but are not used so widely for the treatment of respiratory tract infections. This is because of their limited potency against clinically important organisms, including $S$ pneumonia and staphylococci, as well as enterococci (12). Grepafloxacin is a recently developed fluorinated quinolone with enhanced activity against these pathogens and with altered pharmacokinetics. Compared with ciprofloxacin, the most potent fluoroquinolone clinically available, grepafloxacin carries two additional methyl groups, one at position $\mathrm{C}^{-5}{ }^{\prime}$ of the quinolone ring and the other at position $\mathrm{C}-3^{\prime}$ of the piperazinyl moiety. These modifications enhance activity against Gram-positive bacteria. In addition, the latter methyl group controls pharmacokinetic properties $(13,14)$. In this paper the pattern of activity, the pharmacodynamics and the kill kinetics of grepafloxacin will be reviewed, and the development of resistance will be discussed.

Reprinted from the Journal of Antimicrobial Chemotherapy 1997;40(Suppl A):19-25 by permission of The British Society for Antimicrobial Chemotherapy and Oxford University Press

Pharmaceutical Microbiology, University of Bonn, Meckenheimer Allee 168, D-53115 Bonn, Germany 


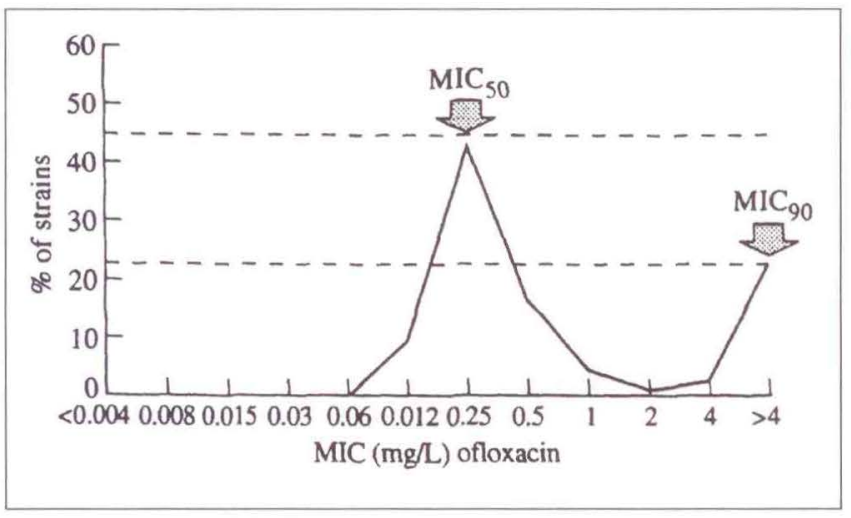

Figure 1) Distribution of ofloxacin minimum inhibitory concentration against 768 Staphylococcus aureus strains (19)

\section{SPECTRUM OF ACTIVITY OF GREPAFLOXACIN}

Antibacterial activity is usually assessed by determining minimum inhibitory concentrations (MICs), which are presented as $\mathrm{MIC}_{50}$, MIC90 and MIC range. However, the distribution of MICs is much more informative. For example, the MIC 90 is often used to compare related and unrelated drugs, but this value is strongly influenced by the total number of resistant strains. If $10 \%$ of tested strains are resistant, especially with quinolones, the $\mathrm{MIC}_{90}$ may be 64 -fold higher or more than that for $9 \%$ resistant strains. As demonstrated in Figure 1, where ofloxacin activity against $S$ aureus is given as an example, the $\mathrm{MIC}_{50}$ represents the peak of the naturally sensitive population without acquired resistance, and therefore represents the real intrinsic activity of the drug much better. More than $20 \%$ of the strains are resistant to ofloxacin. Thus, the MIC9o repre- sents the resistant population. The intrinsic activity, however, is represented by the $\mathrm{MIC}_{50}$, as the $\mathrm{MIC}_{50}$ is at the exact centre of the Gaussian distribution of the naturally occurring population of sensitive strains without mutation in the grlA or gyrA genes. The activity of grepafloxacin will therefore be discussed here in terms of $\mathrm{MIC}_{50} \mathrm{~S}$, as these are not influenced by the number of resistant strains. The development of resistance has to be considered separately, as these two phenomena are not related.

Grepafloxacin is active against both Gram-positive and Gram-negative bacteria (15-18). Table 1 lists bacteria according to their $\mathrm{MIC}_{50}$ S. Gram-negative bacteria such as Haemophilus influenzae, Neisseria gonorrhoeae, E coli, Shigella species and Moraxella catarrhalis are most sensitive. However, the majority of important pathogens, such as staphylococci, especially $S$ aureus (methicillin-resistant or -sensitive), but also most Gram-negative bacteria, including Enterobacteriaceae and Acinetobacter species, are inhibited by $0.03 \mathrm{mg} / \mathrm{L}$ grepafloxacin. Streptococci are inhibited by $0.125 \mathrm{mg} / \mathrm{L}$ and enterococci by $0.25 \mathrm{mg} / \mathrm{mL}$, comparable to the less sensitive Gram-negative bacteria, Pseudomonas aeruginosa, Serratia marcescens and others. Some Enterococcus faecium strains have MICs of $4 \mathrm{mg} / \mathrm{L}$, while Enterococcus faecalis and Enterococcus avium are inhibited by $0.5 \mathrm{mg} / \mathrm{L}$. The activity against anaerobes is also low (eg, $2 \mathrm{mg} / \mathrm{L}$ for Bacteroides fragilis). Thus, most species are included in grepafloxacin's spectrum of activity if a more sensitive or more resistant breakpoint (1 mg/L or less and $4 \mathrm{mg} / \mathrm{L}$ or more, respectively) is assumed from the values obtained with other quinolones.

MIC distributions (19): Figure 2 shows the distribution of MICs againsg $E$ coli; it can be seen that ciprofloxacin and gre-

TABLE 1

Intrinsic activity of grepafloxacin given as minimum inhibitory concentration (MIC) 50 values (15-18)

\begin{tabular}{|c|c|c|}
\hline $\mathrm{MIC}_{50}(\mathrm{mg} / \mathrm{L})$ & Gram-positive bacteria & Gram-negative bacteria \\
\hline 0.004 & - & Haemophilus influenzae (15) \\
\hline 0.008 & - & $\begin{array}{l}\text { Escherichia coli (15), Shigella species (15), Neisseria gonorrhoeae } \\
\text { (15), Moraxella catarrhalis (15) }\end{array}$ \\
\hline 0.016 & Bacillus cereus (15) & $\begin{array}{l}\text { Yersinia enterocolitica (15), Acinetobacter species (15), Salmonella } \\
\text { enteritidis (15) Citrobacter diversus (15), Enterobacter } \\
\text { agglomerans (15) }\end{array}$ \\
\hline 0.031 & $\begin{array}{l}\text { Staphylococcus aureus (15), Streptococcus equisimilis (15), } \\
\text { Staphylococcus haemolyticus (15), Staphylococcus hominis (16) }\end{array}$ & $\begin{array}{l}\text { Citrobacter freundii (15), Enterobacter aerogenes (15,16), } \\
\text { Enterobacter cloacae }(15,16) \text {, Enterobacter salazakii }(16), \\
\text { Salmonella species (16), Klebsiella oxytoca }(15,16), \text { Klebsiella } \\
\text { pneumoniae }(15,16) \text {, Citrobacter diversus (16), Acinetobacter } \\
\text { baumanii (16), Acinetobacter Iwoffii (16) }\end{array}$ \\
\hline 0.062 & Staphylococcus epidermidis (16), S haemolyticus (16) & $\begin{array}{l}\text { Morganella morganii (15), Proteus vulgaris }(15,16), \text { C freundii (16), } \\
\text { Aeromonas hydrophila (16) }\end{array}$ \\
\hline 0.125 & $\begin{array}{l}\text { C jekeiium (15), group B streptococci (15), Streptococcus species } \\
\text { (16) Streptococcus pneumoniae (15), Streptococcus } \\
\text { saprophyticus (16) }\end{array}$ & $\begin{array}{l}\text { Proteus mirabilis (15), Providencia stuarti (15), Proteus rettgeri (15) } \\
\text { Serratia marcescens (15), Serratia liquefaciens (15), } \\
\text { M morganii (16) }\end{array}$ \\
\hline 0.25 & Enterococcus faecalis $(15,18)$, group A,C,F, G streptococci (15) & $\begin{array}{l}\text { P aeruginosa (15), P mirabilis (16), } 5 \text { marcescens (16), Chlamydia } \\
\text { pneumoniae (17) }\end{array}$ \\
\hline 0.5 & E faecalis (16), Enterococcus avium (16), Enterococcus faecium (18) & $\begin{array}{l}\text { Stenotrophomonas maltophilia }(15,16), P \text { aeruginosa }(16), \\
\text { Flavobacterium species }(16)\end{array}$ \\
\hline 1 & - & - \\
\hline 2 & E faecium (16) & Bacillus fragilis (15), P stuartii (16), Bacteriodes bivius diseins (15) \\
\hline 4 & E faecium (15) & P rettgeri (16) \\
\hline
\end{tabular}




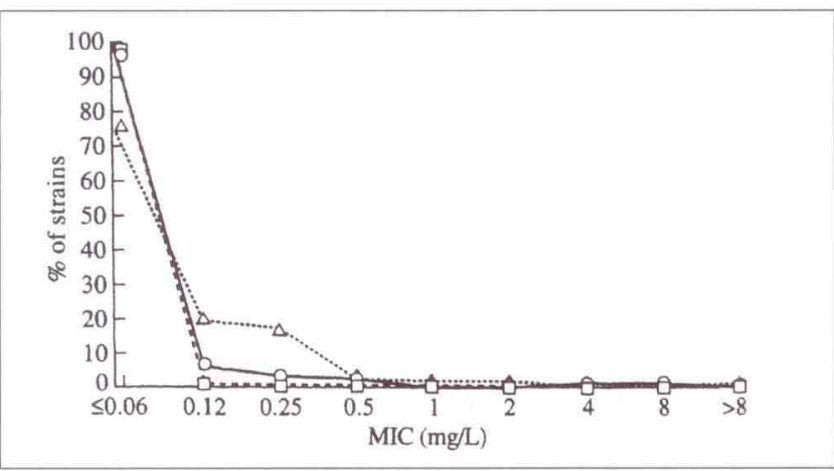

Figure 2) Distribution of ciprofloxacin (O), grepafloxacin $\square$ ) and ofloxacin $(\Delta)$ minimum inhibitory concentration against 1008 Escherichia coli strains (19)

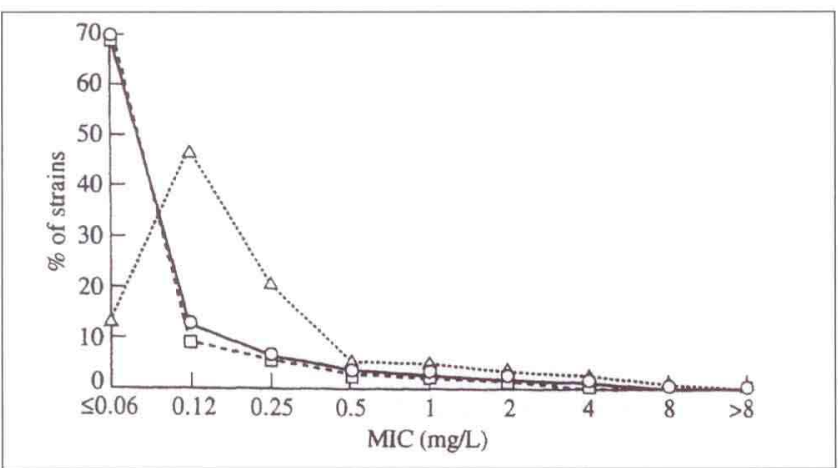

Figure 3) Distribution of ciprofloxzcin (O), grepafloxacin $\square$ ) and ofloxacin $(\Delta)$ minimum inhibitory concentrations against $387 \mathrm{Kleb}$ siella pneumoniae strains (19)

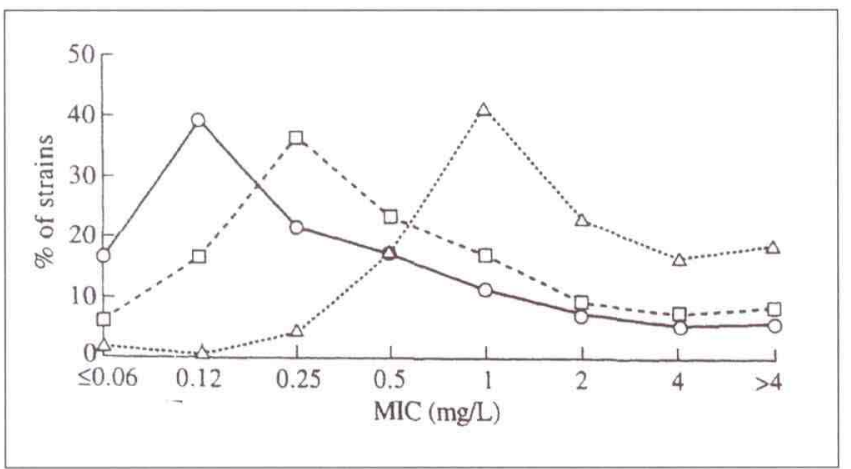

Figure 4) Distribution of ciprofloxzcin (O), grepafloxacin ( $\square$ ), and ofloxacin ( $\Delta$ ) minimum inhibitory concentrations against 651 Pseudomonas aeruginosa strains (19)

pafloxacin have nearly identical activity, while the activity of ofloxacin is slightly lower. The profile for $K$ pneumoniae (Figure 3 ) is similar. Against $P$ aeruginosa, grepafloxacin is only half as active as ciprofloxacin, but four times more active that ofloxacin (Figure 4). Against Gram-positive bacteria like $S$ aureus grepafloxacin is four to eight times more active than other drugs (Figure 5), even if methicillin-resistant strains are included. Most methicillin-resistant strains are resistant to quinolones as well, the MICs for all drugs tested being $4 \mathrm{mg} / \mathrm{L}$ or greater (15). Against group A and B streptococci, grepafloxacin is twice as active as ciprofloxacin and four times as active as

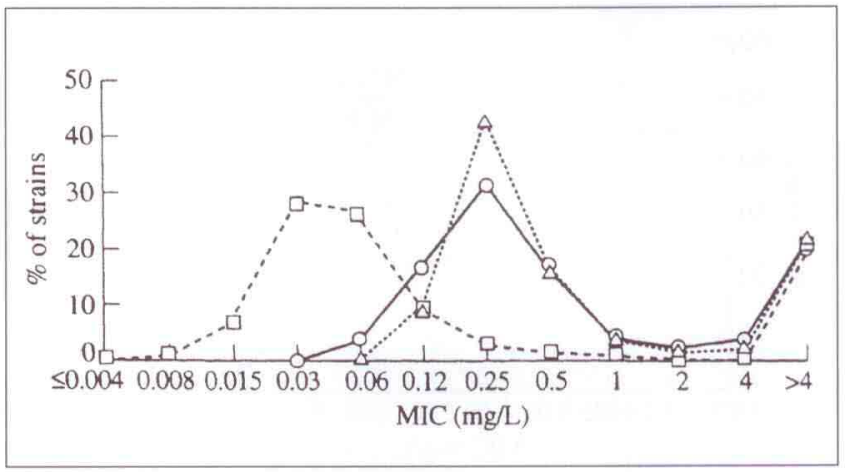

Figure 5) Distribution of ciprofloxzcin (O), grepafloxacin $\square$ ) and ofloxacin $(\Delta)$ minimum inhibitory concentrations against 768 Staphylococcus aureus strains (19)

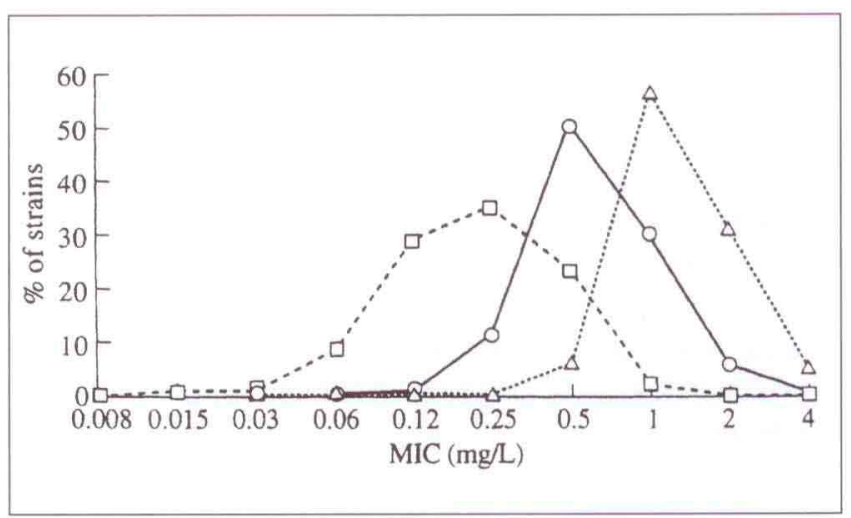

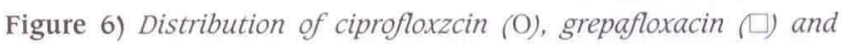
ofloxacin $(\Delta)$ minimum inhibitory concentrations against 119 strains of group A and B streptococci (19)

ofloxacin (Figure 6). the improvement towards Gram-positive bacteria is best shown with $S$ pneumoniae (Figure 7; AL Barry, personal communication), where grepafloxacin is four times more active than ciprofloxacin and 16 times more active than fleroxacin. There were no differences in grepafloxacin MICs against penicillin-sensitive, -intermediate and -resistant strains (Table 2). Grepafloxacin is one of the most effective fluoroquinolones against these species (Table 3), only trovaflxacin and the new derivative DU-6859a being more active (21).

\section{DEVELOPMENT OF RESISTANCE}

In the early days of fluorinated quinolones it seemed as if some bacteria would never become resistant towards these new drugs. However, after several years of widespread use of fluoroquinolones even $E$ coli has developed significant resistance towards fluoroquinolones (22-24). By sophisticated methods it has been shown that, in $E$ coli, several mutations are necessary to render an $E$ coli strain clinically resistant to ciprofloxacin: a double mutation in the gyrA gene encoding subunit A of DNA gyrase (25), additional mutations in the parC gene encoding topoisomerase IV (7), and alterations in the outer membrane are needed (26). Following serial exposure to grepafloxacin or to ciprofloxacin, Gram-negative bacilli develop resistance to the selected agents. Those resistant mutants showed cross-resistance to all other fluoroqui- 


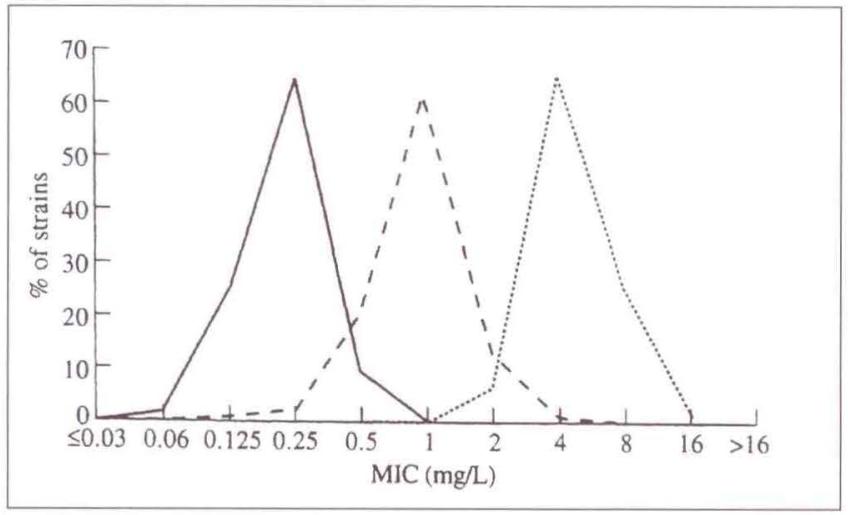

Figure 7) Distribution of ciprofloxzcin (--), grepafloxacin (-), and fleroxacin (....) minimum inhibitory concentrations against 698 Streptococcus pneumoniae strains (2O and AL Barry, personal communications)

\section{TABLE 2}

In-vitro activity of grepafloxacin against penicillinsusceptible, -intermediate and -resistant Streptococcus pneumoniae isolates $(\mathrm{N}=698)(18)$

\begin{tabular}{lccc}
\hline Organism & Susceptible & Intermediate & Resistant \\
\hline Number & 514 & 117 & 66 \\
$M I C$ range $(\mathrm{mg} / \mathrm{L})$ & $<0.03-1$ & $0.125-0.5$ & $0.125-0.5$ \\
$\mathrm{MIC}_{50}(\mathrm{mg} / \mathrm{L})$ & 0.25 & 0.25 & 0.25 \\
$\mathrm{MIC}_{90}(\mathrm{mg} / \mathrm{L})$ & 0.25 & 0.25 & 0.25 \\
$\%<0.25 \mathrm{mg} / \mathrm{L}$ & 91 & 93 & 94 \\
$\%$ susceptible & 100 & 100 & 100 \\
\hline
\end{tabular}

MIC Minimum inhibitory concentration

nolones (Figure 8) and to nalidixic acid (18). Spontaneously occurring resistant mutants will be observed at a frequency of $10^{-7}$ to less than $10^{-11}$ with Gram-negative bacilli. Such mutants are rare among multiresistant $S$ aureus and enterococci. The results of these experiments vary with the experimental conditions, but in general it seems that ciprofloxacin and grepafloxacin do not select resistant $E$ coli, E faecium or $E$ faecalis in the presence of subinhibitory conditions. With grepafloxacin $S$ aureus did not show an increase of the MIC while $E$ faecalis did, but only by one dilution step. With ciprofloxacin, however, the increases in the MIC using the same procedure were five to seven serial dilution steps. Similar results were obtained by Sader et al (19) with the lowest frequency of mutation seen in $E$ faecalis (less than $9 \times 10^{-10}$ ) and highest in $P$ aeruginosa $\left(1.8 \times 10^{-7}\right)$. Whether the selection of resistant mutants in vivo will follow the in vitro results is questionable and difficult to evaluate because of the simultaneous use of several quinolones in most hospitals.

Defined mutants of $E$ coli did not show significantly different responses to ciprofloxacin and grepafloxacin (Table 4 [27]). Two different mutations in the gyrA gene increased the ciprofloxacin and grepafloxacin MICs by five and four dilutions, respectively. The same held true for the acquisition of a second gyrA mutation in a gyrA-parC double mutant and a parC mutation in a gyrA double mutant. The same difference in the MIC increase occurred after acquisition of a marR deletion.
TABLE 3

In-vitro susceptibility (mg/L) of pneumococci (21)

\begin{tabular}{lccc}
\hline Drug & MIC range & MIC $_{50}$ & MIC $_{90}$ \\
\hline Ciprofloxacin & $0.5-4.0$ & 2 & 4 \\
Ofloxacin & $0.5-4.0$ & 2 & 4 \\
Levofloxacin & $0.5-2.0$ & 1 & 2 \\
Lomefloxacin & $2-16$ & 4 & 8 \\
Tosulfloxacin & $0.064-0.5$ & 0.25 & 0.25 \\
Sparfloxacin & $0.064-1.0$ & 0.25 & 0.5 \\
DU-6859a & $<0.008-0.125$ & 0.064 & 0.125 \\
Grepafloxacin & $0.125-1.0$ & 0.25 & 0.5 \\
Trovafloxacin & $0.064-0.5$ & 0.125 & 0.25 \\
\hline
\end{tabular}

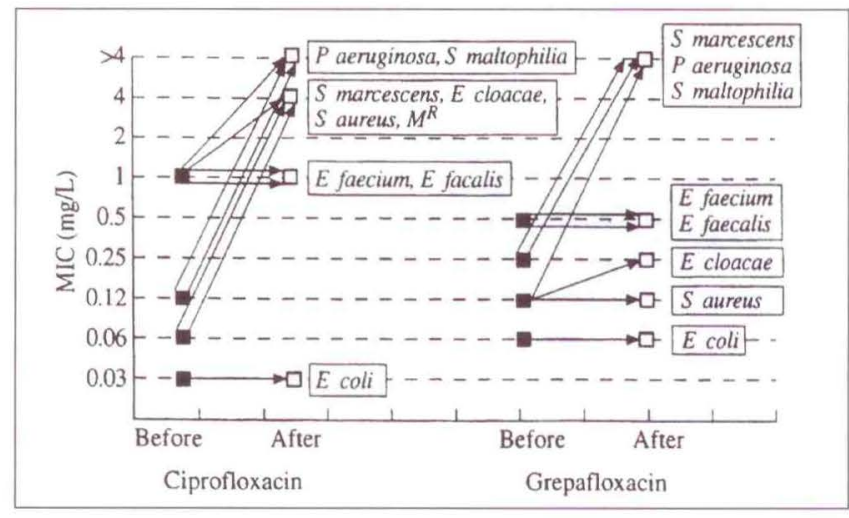

Figure 8) Development of resistant mutants of bacterial strains following 10 serial transfers in subinhibitory concentrations of grepafloxacin or ciprofloxacin (18)

\section{KILL KINETICS}

According to Barry (18), ciprofloxacin and grepafloxacinkill bacteria most effectively at the MIC or a $2 \times$ MIC (Figure 9). Only one-fifth of experiments revealed a minimum bactericidal concentration $(\mathrm{MBC})$ at $4 \times \mathrm{MIC}$. Differences between grepafloxacin and ciprofloxacin were not significant. Ciprofloxacin, however, initially killed more rapidly. With both drugs regrowth frequently occurred after 24 to $48 \mathrm{~h}$ incubation at these low concentrations (18). Wakebe and Mitsuhashi (28) compared the bactericidal activity of grepafloxacin with those of ciprofloxacin and ofloxacin against $S$ aureus, E coli and $P$ aueruginosa. The pattern of killing was very similar for all drugs, if concentrations between $0.25 \times$ MIC and $2 \times$ MIC were used in the experiments. For $S$ aureus, however, the MIC was much lower, indicating that grepafloxacin is more potent than the other drugs tested.

To determine the pharmacodynamic properties of a drug it is necessary to simulate its pharmacokinetics. We used $S$ pneumoniae, $M$ catarrhalis and $H$ influenzae as the clinically most important respiratory tract pathogens in an in-vitro model (29) simulating the pharmacokinetics of a $400 \mathrm{mg}$ dose of grepafloxacin. Figure 10 demonstrates the high activity of the drug. Even after a single dose of the drug the viable cell counts of all three bacterial species were steadily reduced by nearly five to six orders of magnitude within $24 \mathrm{~h}, M$ catarrhalis being the most sensitive. The long half-life of the drug en- 
TABLE 4

Comparative activity of ciprofloxacin and grepafloxacin against mutants of Escherichia coli (27)

\begin{tabular}{lccccc}
\hline & & & \multicolumn{2}{c}{$\begin{array}{c}\text { Change in MIC } \\
\text { (serial twofold dilution steps) }\end{array}$} \\
gyrA & gyr $B$ & parC & marR & Ciprofloxacin & Grepafloxacin \\
\hline A & - & - & - & 5 & 4 \\
A, E & - & E & E & 5 & 4 \\
E, E & - & A & - & 5 & 4 \\
E & - & - & A & 3 & 2 \\
E & E & E & A & 1 & 1 \\
\hline
\end{tabular}

A Additional mutation; E Existing mutation; MIC Minimum inhibitory concentration

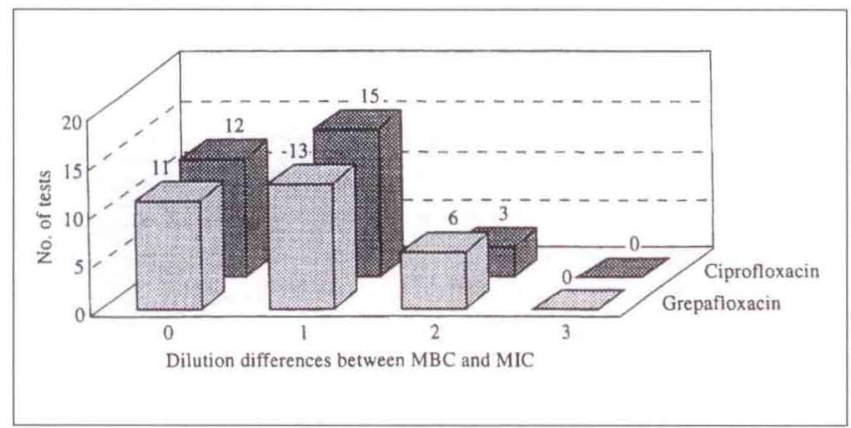

Figure 9) Bactericidal concentrations of grepafloxacin and ciprofloxacin. The number of twofold dilutions below the minimum inhibitory concentration (MIC) (increasing concentration) was tested for 30 strains including three strains of each of the following: Staphylococcus aureus (methicillin resistant), Enterococcus faecalis, Enterococcus faecium, Streptococcus agalactiae, Escherichia coli, Klebsiella pneumoniae, Serratia marcescens, Pseudomonas aeruginosa and S maltophilia (18)

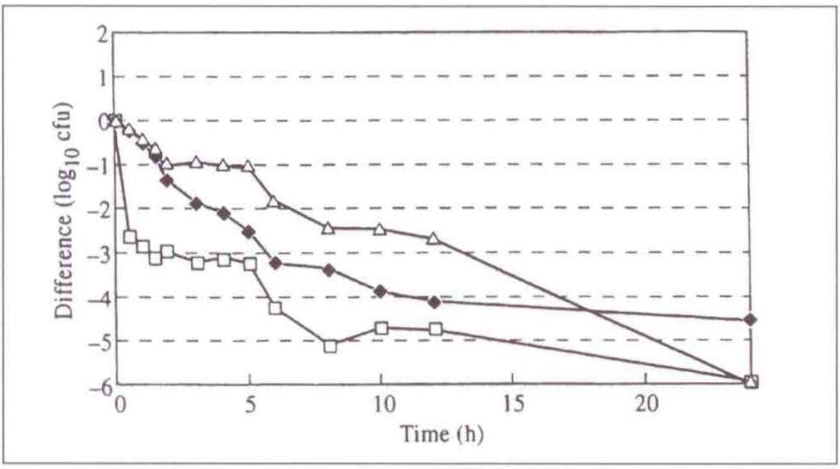

Figure 10) The kill-kinetics of Haemophilus influenzae $(\Delta)$, Streptococcus pneumoniae ( ) and Moraxella catarrhalis ( $\square$ ) after simulation of a single $400 \mathrm{mg}$ dose of grepafloxacin with $24 \mathrm{~h}$ (29). The pharmacokinetic data were from Glaxo Wellcome (1996) Grepafloxacin Consultants' Manual, with $C_{\max }=1.4 \mathrm{mg} / \mathrm{L}$ and $t_{1 / 2}=13.7 \mathrm{~h}$

sured that regrowth did not occur at any time during the experiment $(24 \mathrm{~h})$. Comparing these data with a $500 \mathrm{mg}$ dose of ciprofloxacin against $S$ pneumoniae (Figure 11), it is obvious that the better pharmacodynamic properties of grepafloxacin result in superior activity. Ciprofloxacin reduced the inoculum by only one order of magnitude before the

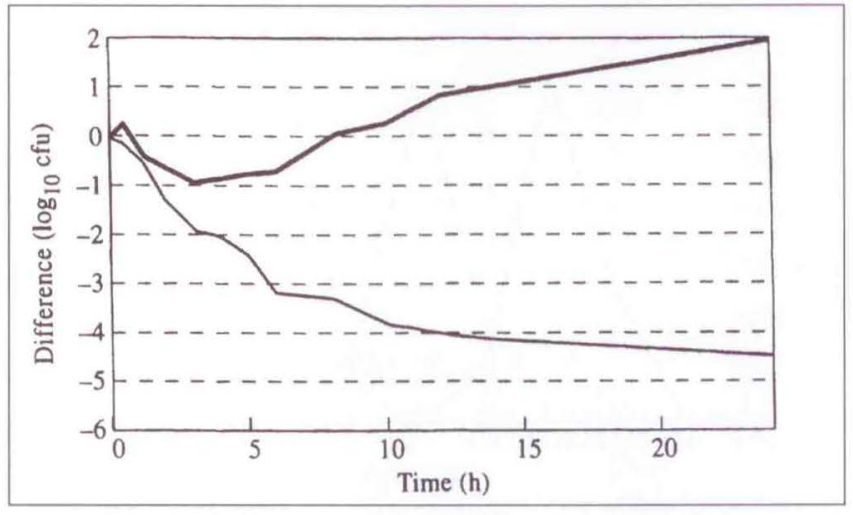

Figure 11) The kill kinetics within 24 h against Streptococcus pneumoniae strains after application of a single $500 \mathrm{mg}$ dose of ciprofloxacin (upper curve) in comparision with that of a single dose of $400 \mathrm{mg}$ grepafloxacin (lower curve)

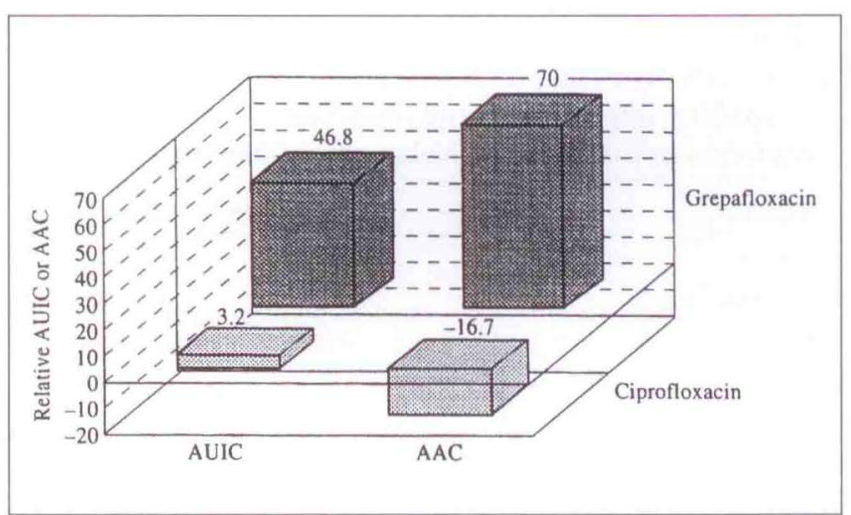

Figure 12) Comparison of relative inhibitory area under the curve (AUIC) and area above the curve $(A A C)$ values for grepafloxacin and ciprofloxacin demonstrating the superior antibacterial activity of grepofloxacin towards Streptococcus pneumoniae

number of viable bacteria increased. We calculated the area under the inhibitory curve (AUIC) and, as a measure of the number of killed bacteria, the area above the curve (AAC), making the area below the inoculum positive, and that above the inoculum negative (as this means an increase in the number of bacteria). Both parameters demonstrate the favourable pharmacodynamic properties of grepafloxacin as compared with ciprofloxacin (Figure 12). Schentag (30) proposed an AUIC value of more than 125 as predictive for therapeutic success. As our data in contrast to Shentag's patient data are obtained from in vitro experiments AUIC values cannot be evaluated accordingly.

\section{CONCLUDING REMARKS}

Grepafloxacin contains two more methyl groups than ciprofloxacin, and this broadens its antimicrobial spectrum to include a wider range of Gram-positive bacteria, including pneumococci. The favourable pharmacokinetic parameters may be possible and MICs indicate once daily dosing may be possible. The pharmacodynamic activity of grepafloxacin against $S$ pneumoniae indicates that this drug may be promising for the treatment of respiratory tract infections. 


\section{REFERENCES}

1. Goss WA, Deitz WH, Cook TM. Mechanism of action of nalidixic acid on Escherichia coli. II. Inhibition of deoxyribonucleic acid synthesis. J Bacteriol 1965;89:1068-74.

2. Gellert M, Mizuuchi K, O'Dea MH, Itoh T, Tomizawa JI. Nalidixic acid resistance: a second genetic character involved in DNA gyrase activity. Proc Natl Acad Sci USA 1977;74:4772-6.

3. Sugino A, Peebles CL, Kreuzer KN, Cozzarelli NR. Mechanism of action of nalidixic acid: purification of Escherichia coli nalA gene product and its relationship to DNA gyrase and a novel nicking-closing enzyme. Proc Natl Acad Sci 1977;74:4767-71.

4. Hoshino K, Kitamura A, Morrissey I, Sato K, Kato JI, Ikeda H. Comparison of inhibition of Escherichia coli topoisomerase IV by quinolones with DNA gyrase inhibition. Antimicrob Agents Chemother 1994;38:2623-7.

5. Khodursky AB, Zechiedrich EL, Cozzarelli NR. Topoisomerase IV is a target of quinolones in Escherichia coli. Proc Natl Acad Sci USA 1995;92;11801-5.

6. Belland RJ, Morrison SG, Ison C, Huang WM. Neisseria gonorrhoeae acquires mutations in analogous regions of gyrA and parC in fluoroquinolone-resistant isolates. Mol Microbiol 1994;14:371-80.

7. Heisig P. Genetic evidence for a role of parC mutations in development of high-level fluoroquinolone resistance in Escherichia coli. Antimicrob Agents Chemother 1996;40:879-85

8. Georgiou M, Muñoz R, Román F, et al. Ciprofloxacin-resistant Haemophilus influenzae strains possess mutations in analogous positions of GyrA and ParC. Antimicrob Agents Chemother 1996;40:1741-4

9. Ferrerro L, Cameron B, Manse B, et al. Cloning and primary structure of Staphylococcus aureus DNA topoisomerase IV: a primary target of fluoroquinolones. Mol Microbiol 1994;13:641-53.

10. Pan XS, Fisher LM. Cloning and characterization of the parC and parE genes of Streptococcus pneumoniae encoding DNA topoisomerase IV: role in fluoroquinolone resistance. J Bacteriology 1996;178:4060-9.

11. Pan XS, Fisher LM. Targeting of DNA gyrase in Streptococcus pneumoniae by sparfloxacin: selective targeting of gyrase or topoisomerase IV by quinolones. Antimicrob Agents Chemother 1997;41:471-4

12. Paganoni R, Herzog C, Braunsteiner A, Hohl P. Fleroxacin: in-vitro activity worldwide against 20,807 clinical isolates and comparison to ciprofloxacin and norfloxacin. J Antimicrob Chemother 1988;22(Suppl D):3-17

13. Akiyama H, Koike M, Nii S, Oghuro K, Odomi M. OPC-17116, an excellently tissue-penetrative new quinolone: pharmacokinetic profiles in animals and antibacterial activities of metabolites. 31st Interscience Conference on Antimicrobial Agents and Chemotherapy, Chicago, 1991. (Abst 1477)

14. Domagala JM. Structure-activity and structure-side-effect relationships for the quinolone antibacterials. I Antimicrob Chemother 1994:33:685-706

15. Sader HS, Erwin ME, Jones RN. In vitro activity of OPC-17116 compared to other broad-spectrum fluoroquinolones. Eur J Clin Microbiol Infect Dis 1992;11:372-81.
16. Mario F, Jones RN, Hoban DJ, Pignatari AC, Yamune N, Frei R. In-vitro activity of OC-17116 against more than 6000 consecutive clinical isolates: a multicentre international study. J Antimicrob Chemother 1994:33:647-54.

17. Hamerschlag MR. Antimicrobial susceptibility and therapy of infections caused by Chlamydia pneumoniae. Antimicrob Agents Chemother 1994;38:1873-8.

18. Barry AL. In vitro activities of OPC-17116 and five other fluoroquinolones. 32nd Interscience Conference on Antimicrobial Agents and Chemotherapy, Anaheim, 1992. (Abstract 779)

19. Sader HS, Jones RN, Allen SD, Gerlach EH, Murray PR, Washington JA. In vitro comparison activity of OPC-17116, a new fluoroquinolone, against more than 5000 recent clinical isolates from five medical centers. J Chemother 1993;5:283-8.

20. Fuchs PC, Barry AL, Brown SD. Tentative interpretive criteria for testing the susceptibility of Streptococcus pneumoniae to eight fluoroquinolones. Diagn Microbiol Infect Dis 1996;26:23-7.

21. Pankuch GA, Jacobs MR. Appelbaum PC. Activity of CP99,219 compared with DU-6859, ciprofloxacin, ofloxacin, levofloxacin, lomefloxacin, tosulfloxacin, sparfloxacin and grepafloxacin aginst penicillin-susceptible and-resistant pnemonococci. J Antimicrob Chemother 1995;35:230-2.

22. López-Brea M, Alarcón T. Isolation of fluoroquinolone-resistant Eschericha coli and Klebsiella pneumoniae from an infected Hickman catheter. Eur J Clin Microbiol Infect Dis 1990;9:345-7.

23. Jonsson $M$, Walder $M$, Forsgren A. First clinical isolate of highly fluorquinolone-resistant Escherichia coli in Scandinavia. Eur J Clin Microbiol Infect Dis 1990;9:851-3.

24. Lehn N, Stöwer-Hoffman J, Kott T, et al. Characterization of clinical isolates of Escherichia coli showing high levels of fluoroquinolone resistance. J Clin Microbiol 1996;34:597-602.

25. Heisig P, Schedletzky H, Falkenstein-Paul H. Mutations in the gyrA gene of a high-level fluoroquinone-resistant clinical isolate of Escherichia coli. Antimicrob Agents Chemother 1993;37:696-701.

26. Heisig P, Tschorny R. Characterization of fluoroquinolone-resistant mutants of Escherichia coli selected in vitro. Antimicrob Agents Chemother 1994;38:1284-91.

27. Heisig P, Wiedemann B. In vitro activity of BAY12-8039 against defined mutants of Escherichia coli and Staphylococcus aureus. 37th Interscience Conference on Antimicrobial Agents and Chemotherapy, Toronto, 1997. (Abst F140)

28. Wakebe $\mathrm{H}$, Mitsuhashi S. Antibacterial activity of OPC-17116, a new quinolone antimiccrobial agent. 31st Interscience Conference on Antimicrobial Agents and Chemotherapy, Chicago, 1991. (Abst 1463)

29. Rustige $\mathrm{C}$, Wiedemann B. Antibacterial activity of lomefloxacin in a pharmacokinetic in vitro model. Antimicrob Agents Chemother 1990;34:1107-11.

30. Schentag JJ, Nix DE, Adelman MH. Mathematical examination of dual individualization principles. I: Relationships between AUC above MIC and area under the inhibitory curve for cefmenoxime, ciprofloxacin, and tobramycin. DICP, Ann Pharmacother 1991;25:1050-7. 


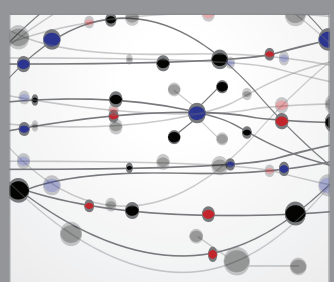

The Scientific World Journal
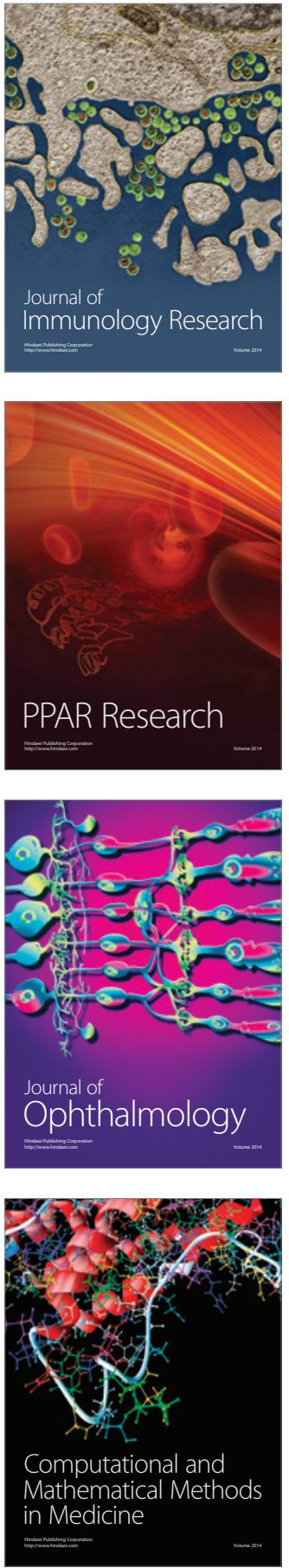

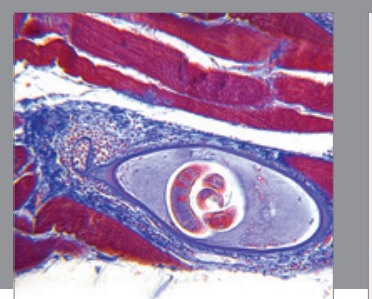

Gastroenterology Research and Practice

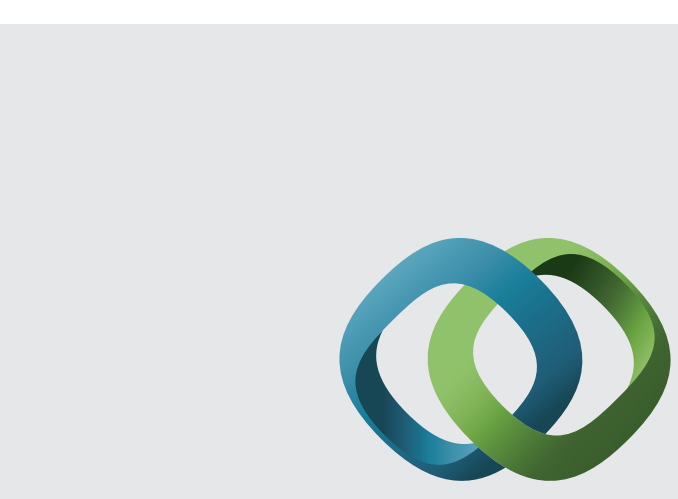

\section{Hindawi}

Submit your manuscripts at

http://www.hindawi.com
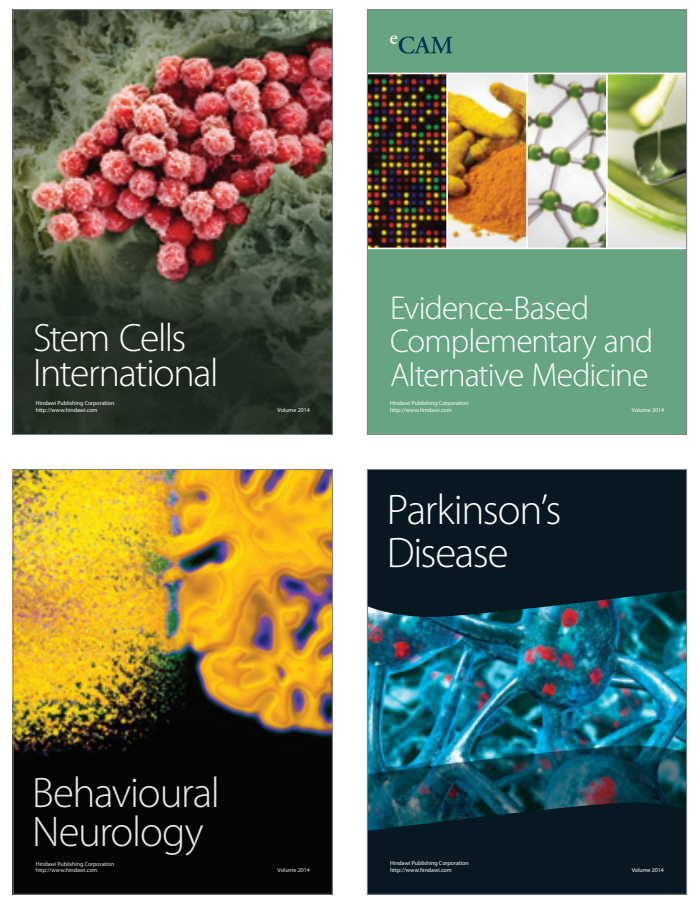
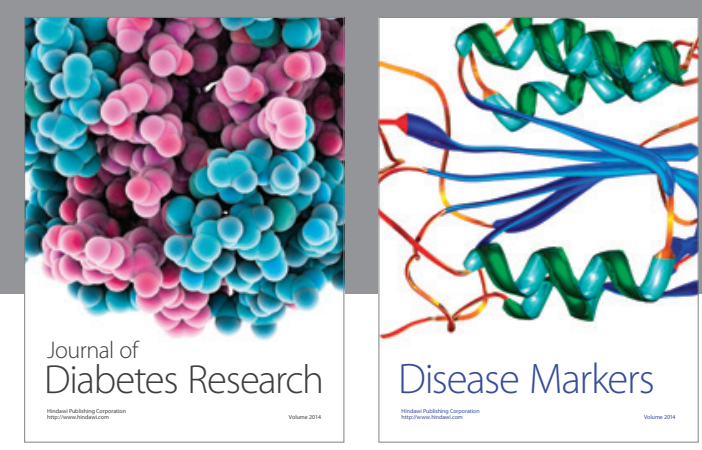

Disease Markers
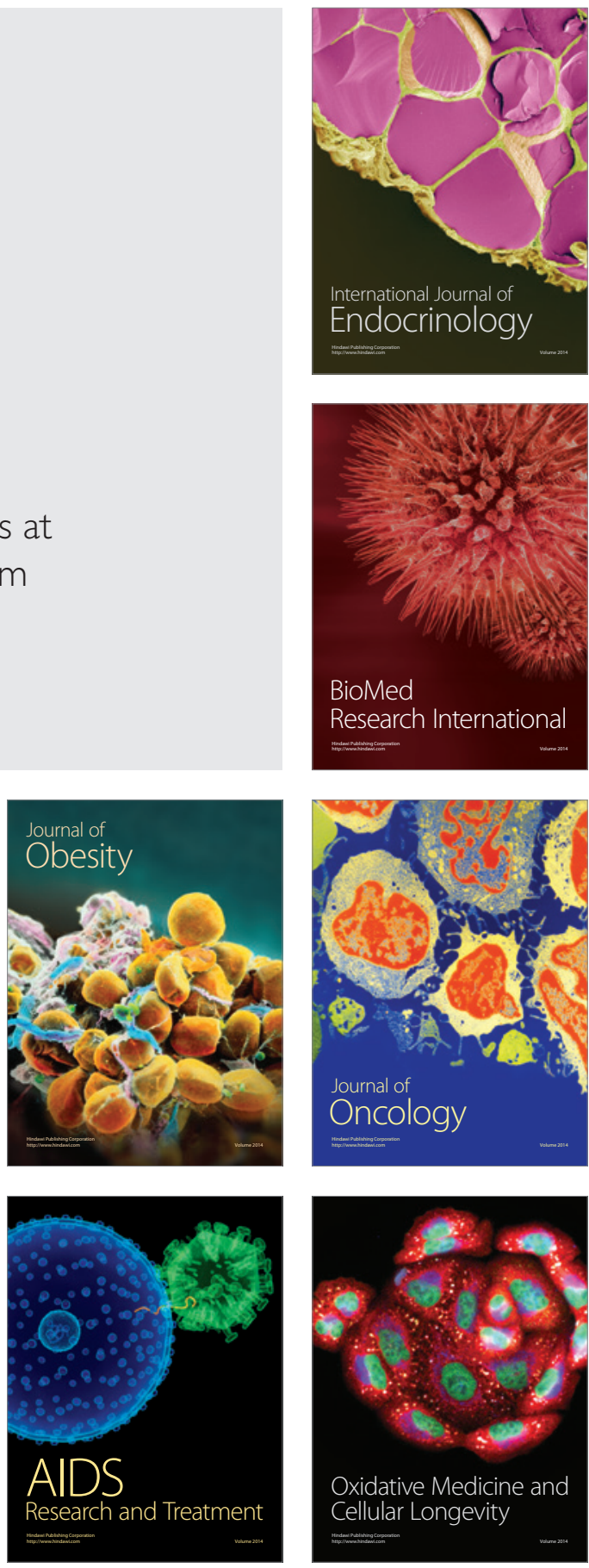